\title{
Survival Strategies of Female Workers: A Study in a Tea Garden of Bangladesh
}

\author{
Md. Kamruzzaman ${ }^{1, *}$, Mohammad Ashraful Islam¹, Sohel Rana ${ }^{2}$, Muhaiminur Rashid ${ }^{3}$ \\ ${ }^{1}$ Department of Agricultural Extension Education, Sylhet Agricultural University (SAU), Bangladesh \\ ${ }^{2}$ Department of Agricultural Economics and Social Sciences, Chittagong Veterinary and Animal Sciences University (CVASU), \\ Bangladesh \\ ${ }^{3}$ Agriculture Information Service (AIS), Ministry of Agriculture, Government of the People's Republic of Bangladesh
}

Copyright $(\mathcal{C} 2015$ by authors, all rights reserved. Authors agree that this article remains permanently open access under the terms of the Creative Commons Attribution License 4.0 International License

\begin{abstract}
The main objective of the study was to determine the survival strategies adopted by the women tea workers in maintaining livelihood. The study was conducted at tea garden of National Tea Industries, at east Shahi Eidgah of Sylhet Headquarters in Bangladesh. Data were collected from 120 women tea workers by simple random sampling throughout January to February, 2014 using interview schedule as principle tool. Most of the women tea workers $(70 \%)$ had medium adoption of survival strategies. The mean adopted survival strategies were higher for food, health \& hygiene and financial aspect than housing and immediate incidence aspect. Taking less preferred cheap food and avoiding protein enriched costly food item in daily diet was the top ranked survival strategy followed by male cut trees from nearby forest $\&$ sells fire wood and drinking salted tea to withstand against scorching sunlight while plucking leaves. Formal education, access to credit and communication media exposure had significant positive relationships with the survival strategies adopted by women tea workers.
\end{abstract}

Keywords Survival Strategies, Female Workers, Tea Garden

\section{Introduction}

The tea industry of Bangladesh dates back to 1857 [1]. At present there are 163 tea estates in Bangladesh. The tea estate covers $1,14,014.39$ ha of the grant area of which $49.82 \%$ i.e. $56,801.99$ ha is under tea plantation [2]. It plays an important role in the national economy through trade balancing and employment generation. It employs 117728 people of ethnic minority directly along with 3,50,000 dependents which constitutes $3.3 \%$ of national employment $[3,4]$. According to Khan et. al. [1] on an average, Bangladesh produces 63 million kilograms tea annually which is $0.81 \%$ to GDP and about $1.0 \%$ to export earnings [3].

Among tea workers more than seventy five percent are women and plucking leaves is their principle duty [4]. Employers prefer to engage women for plucking tea leaves since they do a better job and are paid less than the men. It is very real scenario that women workers of tea garden do not get actual evaluation in terms of financial and social aspects through giving hard working whole day long as well as deprived of minimum level of facilities, low nutritional status, citizenship rights as well [5]. The tea garden workers are considered to be among the poorest and most deprived section of organized labor [6].There is a lot of evidence that the tea workers in Bangladesh especially women live an inferior standard of life compared to that of the major tea producing countries in the world [7]. They lead a very miserable condition of life compare to other sectors such as garments factory, ship breaking industry, and even of brick field workers. It is often claimed that the minimum wage levels are highly insufficient to cover basic needs, because wages in the tea plantation sector are relatively low, even by the plantation sector's standards [8]. The tea worker communities are one of the most vulnerable people of Bangladesh [4].

It is also true that all of the main functions of Bangladesh Tea Board (BTB) are related to the raising of tea cultivation, sustaining quality assurance, and giving license to manufacturers, but only one function is related to the welfare measures for laborers and employees. It is also the same about the Bangladesh Tea Research Institute (BTRI) where there is no research department centering the social and human policy or implementing demands of laborers [7]. Therefore, it is very significant to extend substantial knowledge about the survival strategies adopted by the female workers here. For proper policy planning, the findings would provide a bench mark. Based on this circumstance, the study was conducted with following objectives:

1. To ascertain the survival strategies adopted by the women tea workers; and 
2. To identify the socio-economic characteristics of women tea workers relevant to their adopted survival strategies.

\section{Methodology}

Study area, population and sampling: The study was carried out purposively at Doldoli tea garden, one of the three gardens of National Tea Industries of Bangladesh located at east Shahi Eidgah. The garden is situated on the northern side, at a distance of about 3 kilometers from Sylhet Headquarters in Bangladesh. As sample of the study, 120 female workers out of 186 were selected by simple random sampling.

Variables of the study and their measurement: Various socio-economic characteristics of the women tea workers like age, formal education, experience, household size, number of dependent members, income, access to credit, communication media exposure were considered as the independent variables of the study. The dependent variable was the survival strategies adopted by the female tea workers. Key aspects of livelihood such as food for dietary consumption and pure water for drinking, financial capability to maintain family, health care, housing facilities, actions in immediate incidence/ crisis were taken as the basis of measuring adopted survival strategies of women workers. Thus adopted survival strategies were categorized into five aspects as food, housing, health \& hygiene, financial and immediate incidence. Total 16 statements; four for food, two for housing, three for health \& hygiene, four for financial and three for immediate incidence were prepared. Survival strategies were measured using a four point rating scale for each statement on those five aspects. The method of assigning scores to the four alternatives in each statement was as follows:

\begin{tabular}{cc}
\hline Extent of practice & Scores assigned \\
\hline Frequently & 3 \\
Occasionally & 2 \\
Rarely & 1 \\
Not at all & 0 \\
\hline
\end{tabular}

Thus total score of adopted survival strategies for 16 statements may range from 0 to 48 . On the other hand, Survival Strategy Index for each statement was calculated by following formula:

Survival Strategy Index $(\mathrm{SSI})=3 \times \mathrm{F}+2 \times \mathrm{O}+1 \times \mathrm{R}+$ $0 \times \mathrm{NA}$

Here, F, O, R and NA means total number of women tea workers mentioning frequently, occasionally, rarely and not at all practiced of a particular survival strategy respectively.

Data Collection and analysis: Based on the objectives of the study, a structured interview schedule was prepared. The schedule contains both open and closed forms of questions. Data were collected throughout January to February, 2014 by personal interview. At the end of data collection, the collected data were coded, compiled, tabulated and analyzed. The qualitative data were transferred into quantitative data by appropriate scoring technique. Various descriptive statistical measures such as range, percentage, mean, standard deviation, rank order, correlation, $\mathrm{F}$ test were used for categorization and describing the variables.

\section{Results and Discussions}

Survival strategies adopted by women tea workers: Survival strategies adopted score for women tea garden workers varied from 20 to 43 against the possible range of 0 48. The mean and standard deviation were 30.29 and 4.41 , respectively. They were classified into three categories based on their score of survival strategies adopted and presented in Table-1.

It is revealed from Table-1 that majority (70\%) of the respondents fell in medium category whereas rest of them fell in low and high category in almost equal proportion as 15.8 and 14.2 percent respectively. It indicates that most of the women tea workers adopted different survival strategies to maintain livelihood in a considerable extent. Previous studies conducted in tea garden also confirm various survival strategies adopted by women tea workers $[9,10,11]$.

Aspect wise survival strategies adopted: From Table-2, the average score was $2.10,1.56,1.98,2.04$ and 1.56 for the aspects of food, housing, health \& hygiene, financial and immediate incidence respectively. Since the average value for each aspect could vary from $0-3$, all the mean score exceeds its half value (i.e. $>1.50$ ). It indicates the significant adoption level of survival strategy by women tea workers in each aspect of the study.

Table 1. Respondents category based on survival strategies adopted

\begin{tabular}{|c|c|c|c|c|c|}
\hline SI. No & Category of respondents & Frequency & Percentage & Mean & Standard deviation \\
\hline 1. & Low ( score up to 25.88 ) & 19 & 15.8 & & \\
\hline 2. & Medium (score 25.89- 34.70) & 84 & 70.0 & 30.29 & 4.41 \\
\hline 3. & High (above 34.70) & 17 & 14.2 & & \\
\hline
\end{tabular}


Based on mean score, the aspects were categorized into homogenous sub group as presented in table-2. Aspects within sub group do not significantly different from each other but between sub group differs significantly. It is revealed that women tea workers mostly adopted food, financial and health \& hygiene related survival strategies. Comparatively strategies related to immediate incidence and housing were less frequently adopted and fall in same sub group. Previous studies in different tea gardens revealed that women tea workers mostly face crisis in food, health and economic sectors and struggle for their maintenance $[12,13$, 14].

Table 2. Homogenous subsets for survival strategies of different aspects

\begin{tabular}{cccc}
\hline \multirow{2}{*}{ Aspects } & Sample size & \multicolumn{2}{c}{ Subset for alpha=0.05 } \\
\cline { 3 - 4 } & & 1 & 2 \\
\hline Immediate incidence & & 1.56 & \\
Housing & 1.56 & \\
Health \& hygiene & 120 & & 1.98 \\
Financial & & & 2.04 \\
Food & & 2.10 \\
\hline
\end{tabular}

\section{Ranking of survival strategies adopted to maintain livelihood:}

Adopted survival strategy score for each statement was calculated by using survival strategy index (SSI) and based on SSI, rank order for these statements were made as presented in Table 3.

It is evident from the Table- 3 that taking less preferred cheap food and avoiding protein enriched costly food items in daily diet was ranked top. $59 \%$ respondents practice this strategy frequently and 33\% occasionally. Since their income is poor, they usually take rice with cheap food items like vegetables, pulses as daily diet. They rarely consume fish, meat as its market price is higher and beyond their afford. According to Mojumder and Roy [4] although the workers get rations at a concession, a family can hardly have decent food items on their plate. They indeed have very poor quality and protein-deficient meals.

Next top adopted survival strategy was male cut trees from nearby forest and sells fire wood. About half (49\%) of the respondents follow this strategy frequently and $44 \%$ practice occasionally. Actually the salary got from tea garden is very insufficient for them to meet basic needs. Since tea garden is in isolated location and near to the forest, most of the male member of family collect fire woods from nearby forest and sell them to earn some additional income. Thapa [15] and CEC [16] revealed tea garden workers' strategy of alternate income source and Tirkey \& Gardner [17] found cutting down forest trees and selling them as timber, firewood and charcoal.

Table 3. Ranking of survival strategies adopted to maintain livelihood

\begin{tabular}{|c|c|c|c|c|c|c|}
\hline \multirow[t]{2}{*}{ Survival Strategies } & \multicolumn{4}{|c|}{$\begin{array}{l}\text { Respondents' percentage under each extent } \\
\text { of practice }\end{array}$} & \multirow[t]{2}{*}{ SSI } & \multirow{2}{*}{$\begin{array}{l}\text { Rank } \\
\text { order }\end{array}$} \\
\hline & $\mathrm{F}$ & $\mathrm{O}$ & $\mathrm{R}$ & NA & & \\
\hline \multicolumn{7}{|l|}{ Food } \\
\hline 1. Extent of taking less food/skipping meal & 36 & 42 & 18 & 4 & 252 & 6 \\
\hline $\begin{array}{l}\text { 2. Taking less preferred cheap food and avoiding protein enriched costly } \\
\text { food item in daily diet }\end{array}$ & 59 & 33 & 8 & 0 & 302 & 1 \\
\hline $\begin{array}{l}\text { 3. Using natural channels inside tea garden for drinking \& other purposes } \\
\text { when supply water scarce }\end{array}$ & 29 & 36 & 21 & 14 & 216 & 11 \\
\hline $\begin{array}{l}\text { 4. Planting fruits trees and vegetables around homestead to meet family } \\
\text { demand }\end{array}$ & 38 & 32 & 19 & 11 & 237 & 8 \\
\hline \multicolumn{7}{|l|}{ Housing } \\
\hline $\begin{array}{l}\text { 5. Use of straw, mud and other materials to repair broken residents before } \\
\text { rainy season }\end{array}$ & 25 & 47 & 22 & 6 & 230 & 10 \\
\hline 6. To avail residence facilities, engaging wife as tea garden worker & 10 & 17 & 56 & 17 & 145 & 15 \\
\hline \multicolumn{7}{|l|}{ Health \& hygiene } \\
\hline 7. Planting \& using local medicinal plants to cure from diseases & 27 & 47 & 21 & 5 & 234 & 9 \\
\hline $\begin{array}{l}\text { 8. Drinking salted tea to withstand against scorching sunlight while } \\
\text { plucking leaves }\end{array}$ & 44 & 50 & 6 & 0 & 285 & 3 \\
\hline $\begin{array}{l}\text { 9. Providing package money to NGO (Water Aid, IDEA) to establish } \\
\text { hygienic toilet }\end{array}$ & 36 & 14 & 27 & 23 & 195 & 12 \\
\hline \multicolumn{7}{|l|}{ Financial } \\
\hline 10. Male cut trees from nearby forest and sell fire wood & 49 & 44 & 6 & 1 & 290 & 2 \\
\hline $\begin{array}{l}\text { 11. Females engaging in tea garden to have some financial support in } \\
\text { family }\end{array}$ & 16 & 22 & 55 & 7 & 176 & 13 \\
\hline 12. Rearing poultry and livestock to fetch additional income & 30 & 47 & 21 & 2 & 246 & 7 \\
\hline $\begin{array}{l}\text { 13. Saving weekly money to any reliable person like shopkeeper, mohajon } \\
\text { etc. }\end{array}$ & 52 & 29 & 7 & 12 & 265 & 4 \\
\hline \multicolumn{7}{|l|}{ Immediate incidence } \\
\hline 14. Taking loan from neighbors with interest & 37 & 45 & 17 & 1 & 261 & 5 \\
\hline 15. Selling homestead chores & 2 & 42 & 30 & 26 & 142 & 16 \\
\hline 16. Selling livestock & 2 & 35 & 57 & 6 & 159 & 14 \\
\hline
\end{tabular}

$\mathrm{F}=$ Frequently, $\mathrm{O}=$ Occasionally, $\mathrm{R}=$ Rarely, $\mathrm{NA}=$ Not at all, $\mathrm{SSI}=$ Survival Strategy Index 
Table 4. Correlation between socio-economic characteristics of the women tea workers and their survival strategies adopted $(\mathrm{N}=120)$

\begin{tabular}{|c|c|c|c|c|}
\hline \multirow{2}{*}{ Socio-economic characteristics } & \multirow{2}{*}{$\begin{array}{l}\text { survival strategy } \\
\quad(\mathrm{r} \text { value })\end{array}$} & \multicolumn{2}{|c|}{$\begin{array}{l}\text { Tabulated value } \\
\text { significant at }\end{array}$} & \multirow{2}{*}{ Remarks } \\
\hline & & 0.05 level & $\begin{array}{l}0.01 \\
\text { level }\end{array}$ & \\
\hline Age & 0.136 & & & Not significant \\
\hline Formal education & 0.222 & & & Positively significant at 0.05 level \\
\hline Working experience & 0.117 & & & Not significant \\
\hline Household size & 0.123 & 0.177 & 0.231 & Not significant \\
\hline Number of dependent member & 0.108 & & & Not significant \\
\hline Monthly Income & 0.155 & & & Not significant \\
\hline Access to credit & 0.309 & & & Positively significant at 0.01 level \\
\hline Communication media exposure & 0.214 & & & Positively significant at 0.05 level \\
\hline
\end{tabular}

Next top ranked survival strategy was drinking salted tea to withstand against scorching sunlight while plucking leaves. It is found that $44 \%$ of the respondents drunk frequently and $50 \%$ respondents occasionally. Plucking leaves under scorching sun light hours after hours is very laborious job. It is their indigenous techniques to collect some young leaves, drying in sunlight, boiling and mixing salt with it to make it edible. In tea garden, most of the women workers have a plastic bottle containing that salted tea and consume whole day long.

\section{Relationship between socio-economic characteristics of the women tea workers and their survival strategies adopted to maintain livelihood}

Pearson's product moment correlation co-efficient (r) was computed in order to explore the relationship between the socio-economic characteristics of the women tea workers and their strategies adopted to maintain livelihood. The findings are presented in Table 4 .

The findings indicate that formal education, access to credit and communication media exposure of the respondents had significant positive relationship with their survival strategies adopted. Education increases the knowledge and understanding of the respondents. It enables them to determine better strategies and more adoption of those strategies. According to Ruma and Dipak [18], poor educational status of the tea garden workers is one of the major reasons for insecure livelihood and miserable living condition of the community and Mojumder and Roy [4], stressed both formal and informal education among tea garden community for better livelihood.

Again, more access to credit makes people able to create more income sources. Thus enables them to adopt strategies for better livelihood. Rajasenan [19] recommended easy access to credit for better livelihood of tea garden workers. Exposure to communication media increase their knowhow and make them aware about better livelihood. Thus direct them to adopt more strategies for better living. Das and Islam [20] suggested frequent communication between the people of tea gardens and mainstream society to uplift their livelihood. Thus there are certain socio-economic characteristics of women tea workers that influence their adopted survival strategies. Proper nourishment and maintenance of those characteristics can enable them to adopt more strategies for better livelihood.

\section{Conclusions}

The women tea workers adopted survival strategies centered on food, health \& hygiene and financial solvency. They struggle a lot to manage food items for their family members. Women tea workers try to involve in different extra income source since salary from garden is not enough to maintain livelihood but isolation form mainstream society is a great hindrance here. For health purpose they mostly depend on indigenous and traditional survival strategies.

To increase their adoption of strategies for survival and better livelihood, educational status (adult education, educational campaign etc.) and easy access to different credit opportunity (micro-credit, bank loan etc.) should be improved. Different communication media (radio, television, development workers etc.) should be available to them. Adopted survival strategies should be scientifically proven and ultimately beneficial for them. In this concern, tea garden authority, government and non-government organization should initiate collaborative action.

\section{REFERENCES}

[1] Khan, A. Q., Biswas, A., Saha, A. K. and Motalib, M. A. 2012. Soil Properties of Lalmai Hill, Shalban Bihar and Nilachal Hill of Greater Comilla District and Its Suitability for Tea Plantation. Tea J. Bangladesh, 41:17-26.

[2] PDU. 2010. Monitoring Report, 2010. Project Development Unit (PDU), Bangladesh Tea Board, Sreemangal, Moulvibazar.

[3] Hossain, M. 2011. Country Profile: An overview of Bangladesh Tea. Two and a Bub 58: 19-28.

[4] Majumder, S. C. and Roy, S. C. 2012. Socio-economic 
Conditions of Tea Plantation Workers in Bangladesh: A Case Study on Sreemongal. Indian Journal of Applied Research, 1(10): 37-40.

http://www.theglobaljournals.com/ijar/file.php?val=July_20 12_1356957890_aaddd_File14\%20.pdf

[5] Morser, A. 2010. A Bitter Cup : The Exploitation of Tea Workers in India and Kenya Supplying British Supermarkets, War on Want, London. Retrieved from http://www.waronwant.org/attachments/A\%2520Bitter\%252 0Cup.pdf

[6] Sankrityayana, J. 2006. Productivity, decent work and the tea industry in North Eastern India- Plantation Labour in the West Bengal Tea Industry. International Labour Organisation, Background Paper for 'Productivity \& Decent Work in the Tea Industry: A Consultative Meeting'. New Delhi: International Labour Organisation.

[7] Hassan, A. B. M. E. 2014. Deplorable Living Conditions of Female Workers: A Study in a Tea Garden of Bangladesh. American Journal of Humanities and Social Sciences, 2(2): 121-132. DOI: $10.11634 / 232907811402522$

[8] Oldenziel, J. and Otten, G. 2006. Sustainabilitea, The Dutch Tea Market and Corporate Social Responsibility. SOMOCentre for research on Multinational Corporations. Amsterdam

[9] Biyanwila, J. 2007. Ethnicity and Women Worker Struggles in the Sri Lankan Tea Plantations. Annual Conference on Feminist Economics, Bangkok, Thailand, June 29 -July 1, 2007.

[10] Biswas, S., Chokraborty, D., Berman, S. and Berman, J. 2005. Nutritional Survey of Tea Workers on Closed, Re-opened, and Open Tea Plantations of the Dooars Region, West Bengal, India. Paschim Banga Khet Majoor Samity (West Bengal Agricultural Workers' Association), in association with the International Union of Foodworkers and the American Jewish World Service.

[11] Ahmed, S. 2013. Where no One has Worked Before: Innovations behind WaterAid's WASH Work in Bangladesh Tea Garden Communities. Towards inclusive WASH sharing evidence and experience from the field, WaterAid in Bangladesh.
[12] Talwar, A., Chakraborty, D. and Biswas, S. 2005. Study on Closed and Re-opened Tea Gardens in North Bengal. Paschim Banga Khet Majoor Samity and International Union of Food, Agriculture, Hotel, Restaurant, Catering, Tobacco, Plantation and Allied Workers' Associations (IUF).

[13] Herre, R., Hurst, P., Longley, S. and Luig, B. 2014. Study: Harvesting Hunger Plantation Workers and the Right to Food. Bischöfliches Hilfswerk MISEREOR e.V. Aachen, Germany.

[14] Kurmi, P. 2014. Problem of Educational Attainment of Children, A Case Study of the Tea Garden Labourer's House holds in Derby Tea Estate. Research Journal of Language, Literature and Humanities, 1(4): 1-7.

[15] Thapa, N. 2012. Employment Status and Human Development of Tea Plantation Workers in West Bengal. NRPPD Discussion Paper 11. www.cds.edu/wp-content/uploads/2012/11/NRPPD11.pdf

[16] Center for Education and Communication (CEC). 2007. Behind Closed and Abandoned Tea Gardens-Status Report of India. CEC Working Paper, Conceived by the Information $\&$ Feature Trust (TIFT), New Delhi, India.

[17] Tirkey, L. P. and Gardner, J. S. 2006. The Geo-ecological and Socio-economic Implications of Tea Estate Closures in Darjeeling, Indian Himalaya. International symposium towards sustainable livelihoods and Ecosystems in mountainous regions, 7-9 March 2006, Chiang Mai, Thailand.

[18] Ruma, D. N. and Dipak, N. 2014. Educational Vulnerability and Risk Factors of Tea Garden Workers with Special Reference to Dewan Tea Garden Village, Cachar, Assam, India. International Research Journal of Social Sciences. 3(9): 14-21.

[19] Rajasenan, D. 2010. Livelihood and Employment of Workers in Rubber and Spice Plantations. NRPPD Discussion Paper-6.

http://cds.edu/wp-content/uploads/2012/11/NRPPD6.pdf

[20] Das, T. K. and Islam, S. M. H. Z. 2006. Human Rights of the Tea Gardeners: Case Study of Selected Gardens in Sylhet. Asian Affairs, 28(3): 25-39. 